\title{
SERUM IMMUNOCONGLUTININ LEVELS IN HUMAN AMYLOIDOSIS AND MYELOMATOSIS
}

\author{
BY \\ T. J. MUCKLE \\ Department of Pathology, Royal Victoria Infirmary, University of Newcastle upon Tyne
}

The term immunoconglutinin designates antibody specifically reactive against the normally hidden antigenic determinants of $C^{\prime} 3$ complement which are exposed when it combines with immune complexes (Lachmann and Coombs, 1965). The presence of immunoconglutinin in serum therefore specifically indicates previous humoral immunological activity, and the magnitude of both phenomena show a direct relationship. Depression of serum $C^{\prime} 3$ complement may indicate such activity as well, but is less specific since its level may also be affected in either direction by such non-immunological factors as variation in production and catabolism, or urinary loss. Fuithermore, the immunoconglutinin response to an episode of humoral immunological activity persists for some time, so that its detection is less temporally limited than the relatively transient depression of complement level (Coombs, Coombs, and Ingram, 1961).

Loeschke (1927) originally suggested that amyloid substance might represent tissue deposits of antigenantibody complexes, and Strukov, Serov, and Pavlikhina (1963) have offered evidence which seems to show that autoantibodies to the deposits develop during the course of human and animal amyloidosis. The idea that amyloid substance could be at least partly constructed immunologically may be considered to gain moment from demonstrations by the fluorescent antibody technique of the presence in, or binding by, amyloid of $C^{\prime} 3$ complement (Kochem, 1966; Lachmann, Müller-Eberhard, Kunkel, and Paronetto, 1962; Letterer, Caesar, and Vogt, 1960; Müller-Eberhard and Dalmasso, 1965; Nowosławski and Brzosko, 1965; Vogt and Kochem, 1960).

If antigen-antibody reactions in vivo do play any part in the development of amyloidosis, an elevation in serum immunoconglutinin should be evident at some stage in the disease. In actively progressive amyloidosis such elevations might be expected to be nearly continuous and so almost certainly detectable at any time during its course. Absence of immunoconglutinin elevation in amyloidosis may be taken as evidence either of lack of importance of immunological reactions in the development of the disease, or of incapacity to produce specific antibody to immunologically-bound complement.

In this study, immunoconglutinin levels were estimated in 37 sera from 27 patients with amyloidosis, including three with concomitant myelomatosis; 21 sera from nineteen patients with myelomatosis alone; and one hundred sera from normal subjects.

\section{Method}

The technique of estimating serum immunoconglutinin level used was that described by Coombs and others (1961), Method IIb, in which serial dilutions of the test sera in dilute inactivated horse serum are examined for their ability to agglutinate sheep red cells alexinated by exposure to a suitable natural bovine Forssman antibody followed by horse complement. Controls included in each run comprised:

(1) A known negative serum and one of known positive titre.

(2) The alexinated cells alone to exclude artefactual agglutination.

(3) A $1: 2$ dilution of the test serum with the cell system containing $56^{\circ} \mathrm{C}$. inactivated instead of active horse complement to indicate any irrelevant human antibodies against horse or bovine serum proteins, or incomplete absorption with the red cells.

All sera were examined in duplicate, usually on more than one occasion. If the titre varied in a duplicate by more than one tube, an aliquot of that serum specimen was re-examined upon at least one other occasion.

\section{Material}

Sheep blood was collected into one fifth volume of standard solution of acid-citrate-dextrose. Horse sera as a source of conglutinating complement, and bovine sera for the natural Forssman antibody to sheep red 
cells, were obtained by whipping defibrination of blood, the clots being left in contact with the sera for 6 hours at room temperature to allow completion of the coagulation process.

The technique of immunoconglutinin estimation was practised for several weeks before any of the test sera were examined. Early during this practice period it became apparent that individual sheep, cows, and horses showed considerable variation in the desirable qualities of their respective contributing materials. A number of horse and bovine sera were therefore screened in individual cross-combinations, and the pair giving the most clear-cut conglutination, end-point, and negative with known negative and positive sera were stored at $-35^{\circ} \mathrm{C}$. in aliquot volumes sufficient for a day's tests. Each aliquot was thawed once, on the day of test, and any remaining was discarded. Heat inactivation, absorption, and other manipulations were carried out after thawing on the day of test. Each new lot of sheep red cells was checked before use with sera of known positive titre, and a known negative.

Human blood specimens were collected by venepuncture and allowed to clot at $37^{\circ} \mathrm{C}$. for 4 hours. The sera were separated by centrifugation, and each sample was stored in several aliquots at $-35^{\circ} \mathrm{C}$. until required. The period of such storage varied from one week to nearly 4 years; it had already been established that antibody was stable under these conditions for at least 5 years.

All cases of amyloidosis were proven by biopsy or subsequent autopsy. Criteria for the diagnosis of myelomatosis were paraprotein production in great excess with notable diminution of other immunoglobulins as determined by immunoelectrophoresis, and characteristic bone marrow changes.

\section{Results}

Details of the patients, their diseases, and immunoconglutinin titres are given in Table I (opposite). The incidence of the titres in normal and affected groups is given along with the statistics of Coombs and others (1961) in Table II, and in histogram form in the Figure (overleaf).

Statistical analysis by $\chi^{2}$ tests showed that the range and frequency of immunoconglutinin titres found in normal persons in this study were essentially the same as the normal values given by Coombs and others (1961).

The amyloid group sera titres were significantly raised $(\mathrm{P}=<0.05$ but $>0.01)$, but this difference was due to minor elevations and no titre higher than 1: 8 was found. The values found for the patients with myelomatosis also showed departure from normal, but the level of significance was low $(\mathrm{P}=<0.1$ but $>0.05)$, and there was no apparent correlation of the titres with the presence or absence of associated amyloidosis.

\section{Discussion}

These results show that patients with amyloidosis tend to have slightly higher immunoconglutining titres than normal, and might appear to supporto the concept of an immunological basis for amy loidosis. However, the difference is due mainly to minor rises in patients who had predisposing chronic inflammation and who, from previous reports

TABLE II

COMPARISON OF THE IMMUNOCONGLUTININ TITRES FOR NORMAL PERSONS AFTER COOMBS AND OTHERS (1961) WITH THE PRESENT RESULTS FOR NORMAL PERSONS AND FOR PATIENTS WITH AMYLOIDOSIS AND WITH MYELOMATOSIS

\begin{tabular}{|c|c|c|c|c|c|c|c|c|}
\hline Serum Dilution & $\begin{array}{l}\text { Pos. } \\
1 / 64\end{array}$ & $\begin{array}{l}\text { Pos. } \\
1 / 32\end{array}$ & $\begin{array}{l}\text { Pos. } \\
1 / 16\end{array}$ & $\begin{array}{c}\text { Pos. } \\
1 / 8\end{array}$ & $\begin{array}{c}\text { Pos. } \\
1 / 4\end{array}$ & $\begin{array}{l}\text { Pos. } \\
1 / 2\end{array}$ & $\begin{array}{c}\text { Neg. } \\
1 / 2\end{array}$ & $\begin{array}{c}\text { Total } \\
\text { Sera }\end{array}$ \\
\hline $\log _{2}$ ditto & 6 & 5 & 4 & 3 & 2 & 1 & 0 & Group \\
\hline \multirow{2}{*}{ 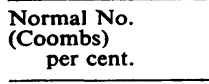 } & 0 & 10 & 35 & 110 & 140 & 321 & 1,873 & 2,489 \\
\hline & $0 \cdot 0$ & 0.4 & $1 \cdot 4$ & $4 \cdot 5$ & $5 \cdot 7$ & $13 \cdot 0$ & $75 \cdot 0$ & \\
\hline \multirow{2}{*}{$\begin{array}{l}\text { Normal No. } \\
\text { (T.J.M.) } \\
\text { per cent. }\end{array}$} & 0 & 0 & 1 & 3 & 7 & 15 & 74 & 100 \\
\hline & 0.0 & 0.0 & $1 \cdot 0$ & $3 \cdot 0$ & $7 \cdot 0$ & $15 \cdot 0$ & $74 \cdot 0$ & \\
\hline \multirow{2}{*}{$\begin{array}{l}\text { Amyloidosis No. } \\
\text { per cent. }\end{array}$} & 0 & 0 & 0 & 3 & 7 & 8 & 19 & 37 \\
\hline & $0 \cdot 0$ & $0 \cdot 0$ & 0.0 & $8 \cdot 1$ & $18 \cdot 9$ & $21 \cdot 6$ & $51 \cdot 4$ & \\
\hline \multirow{2}{*}{$\begin{array}{l}\text { Myelomatosis No. } \\
\text { per cent. }\end{array}$} & 0 & 0 & 1 & 1 & 4 & 4 & 14 & 24 \\
\hline & $0 \cdot 0$ & $0 \cdot 0$ & $4 \cdot 2$ & $4 \cdot 2$ & $16 \cdot 6$ & $16 \cdot 6$ & $58 \cdot 4$ & \\
\hline
\end{tabular}

The three patients with both diseases were included for this purpose in both groups.

$\chi^{2}$ tests showed that the two groups of normal subjects did not differ and that the significance of the deviation from normal shown by the diseased groups was as follows: 
TABLE I

DETAILS AND IMMUNOCONGLUTININ TITRES IN 37 SERA FROM 27 CASES OF AMYLOIDOSIS, THREE OF WHICH WERE ASSOCIATED WITH MYELOMATOSIS; AND IN 21 SERA FROM 19 CASES OF MYELOMATOSIS WITHOUT AMYLOIDOSIS

\begin{tabular}{|c|c|c|c|c|}
\hline $\begin{array}{c}\text { Patient } \\
\text { No. }\end{array}$ & Date & Titre & Condition & Amyloidosis \\
\hline $\begin{array}{l}1 \\
2 \\
3 \\
4 \\
5 \\
6 \\
\\
7 \\
8\end{array}$ & $\begin{array}{l}\text { Sep. } 1962 \\
\text { Nov. } 1964 \\
\text { Dec. } 1964 \\
\text { May } 1966 \\
\text { Jan. } 1965 \\
\text { Jan. } 1965 \\
\text { Feb. } 1965 \\
\text { Nov. } 1966 \\
\text { Dec. } 1964 \\
\text { Jan. } 1965\end{array}$ & $\begin{array}{l}\frac{2}{4} \\
2 \\
2 \\
4 \\
4 \\
2\end{array}$ & $\begin{array}{l}\text { Active Chronic Sepsis } \\
\text { Bronchiectasis } \\
\text { Bronchiectasis } \\
\text { Bronchiectasis } \\
\text { Bronchiectasis } \\
\text { Sinuses (old TB hip) } \\
\text { Sinuses (perineal) } \\
\quad \text { (quiescent) } \\
\quad \text { (cured) } \\
\text { Paraplegia } \\
\text { Paraplegia }\end{array}$ & Perireticulin \\
\hline 9 & Feb. 1965 & 8 & $\begin{array}{l}\text { Previous Chronic Sepsis } \\
\text { Old osteomyelitis }\end{array}$ & Perireticulin \\
\hline 10 & $\left\{\begin{array}{l}\text { Mar. } 1965 \\
\text { May } 1965 \\
\text { Oct. } 1966 \\
\text { Apr. } 1967\end{array}\right.$ & $\begin{array}{r}4 \\
-4\end{array}$ & $\begin{array}{l}\text { Chronic interstitial } \\
\text { pulmonary fibrosis } \\
\text { (idiopathic) }\end{array}$ & Perireticulin \\
\hline $\begin{array}{l}11 \\
12 \\
13 \\
14\end{array}$ & $\left\{\begin{array}{l}\text { May } 1963 \\
\text { May } 1963 \\
\text { Nov. } 1964 \\
\text { Aug. } 1964 \\
\text { Jun. } 1967\end{array}\right.$ & $\frac{\bar{z}}{2}$ & $\begin{array}{l}\text { Previous Tuberculosis } \\
\text { Pulmonary } \\
\text { Pulmonary } \\
\text { Pulmonary } \\
\text { Pulmonary }\end{array}$ & Perireticulin \\
\hline $\begin{array}{l}15 \\
16 \\
17 \\
18 \\
19\end{array}$ & $\begin{array}{l}\text { Dec. } 1962 \\
\text { Jan. } 1963 \\
\text { Nov. } 1962 \\
\text { Jun. } 1965 \\
\text { Oct. } 1966 \\
\text { Sep. } 1962\end{array}$ & $\begin{array}{l}- \\
\overline{4} \\
-\end{array}$ & $\begin{array}{l}\text { Rheumatoid Arthritis } \\
\text { Classical (active) } \\
\text { Classical (active) } \\
\text { Classical (quiescent) } \\
\text { Classical (active) } \\
\text { Old Still's disease }\end{array}$ & Perireticulin \\
\hline $\begin{array}{l}20 \\
21 \\
22\end{array}$ & $\begin{cases}\text { Aug. } & 1964 \\
\text { Jun. } & 1965 \\
\text { Jul. } & 1965 \\
\text { Sep. } & 1965 \\
\text { Jul. } & 1965 \\
\text { May } & 1966\end{cases}$ & $\begin{array}{l}\bar{z} \\
\overline{8}\end{array}$ & $\begin{array}{l}\text { Idiopathic } \\
\text { Generalized } \\
\text { Generalized } \\
\text { Generalized }\end{array}$ & Perireticulin \\
\hline $\begin{array}{l}23 \\
24\end{array}$ & $\begin{array}{l}\text { Mar. } 1965 \\
\text { Dec. } 1962\end{array}$ & $\underline{2}$ & $\begin{array}{l}\text { Idiopathic } \\
\text { Generalized } \\
\text { Localised Dermal }\end{array}$ & Pericollagen \\
\hline $\begin{array}{l}25 \\
26 \\
27\end{array}$ & $\begin{array}{ll}\text { Sep. } 1964 \\
\text { Sep. } 1966 \\
\text { Dec. } 1966\end{array}$ & $\begin{array}{r}2 \\
4 \\
-\end{array}$ & $\begin{array}{l}\text { Myelomatosis } \\
\text { Microglobulin only } \\
\text { IgG } \\
\text { IgG + Microglobulin }\end{array}$ & Pericollagen \\
\hline $\begin{array}{l}28 \\
29 \\
30 \\
31 \\
32 \\
33 \\
34 \\
35 \\
36 \\
37 \\
38 \\
39 \\
40 \\
41 \\
42 \\
43 \\
44 \\
\end{array}$ & $\begin{array}{c}\text { Sep. } 1962 \\
\text { Oct. } 1962 \\
\text { Oct. } 1962 \\
\text { Nov. } 1962 \\
\text { Feb. } 1964 \\
\text { Feb. } 1964 \\
\text { Nov. } 1964 \\
\text { Apr. } 1966 \\
\text { Sep. } 1966 \\
\text { Feb. } 1967 \\
\text { Aug. } 1963 \\
\text { Nov. } 1963 \\
\text { Jul. } 1962 \\
\text { Nov. } 1966 \\
\text { Aug. } 1962 \\
\text { Dec. } 1963 \\
\text { Oct. } 1964 \\
\text { Apr. } 1964 \\
\text { Aug. } 1964\end{array}$ & $\begin{array}{l}\bar{z} \\
\frac{4}{\overline{4}} \\
\frac{2}{\overline{2}} \\
\frac{2}{\overline{-}} \\
\frac{16}{2} \\
\frac{8}{8}\end{array}$ & $\begin{array}{l}\text { Myelomatosis } \\
\text { IgG } \\
\text { IgG } \\
\text { IgG } \\
\text { IgG } \\
\text { IgG } \\
\text { IgG } \\
\text { IgG } \\
\text { IgG } \\
\text { IgG } \\
\text { IgG + Microglobulin } \\
\text { IgA } \\
\text { IgA } \\
\text { IgA + Microglobulin } \\
\text { IgA + Microglobulin } \\
\text { IgA + Microglobulin } \\
\text { Microglobulin only } \\
\text { Microglobulin only }\end{array}$ & None \\
\hline $\begin{array}{l}45 \\
46\end{array}$ & $\begin{array}{l}\text { Jul. } 1964 \\
\text { Mar. } 1967\end{array}$ & $\stackrel{4}{-}$ & $\begin{array}{l}\text { Macroglobulinaemia } \\
\text { IgM } \\
\text { IgM }\end{array}$ & None \\
\hline
\end{tabular}




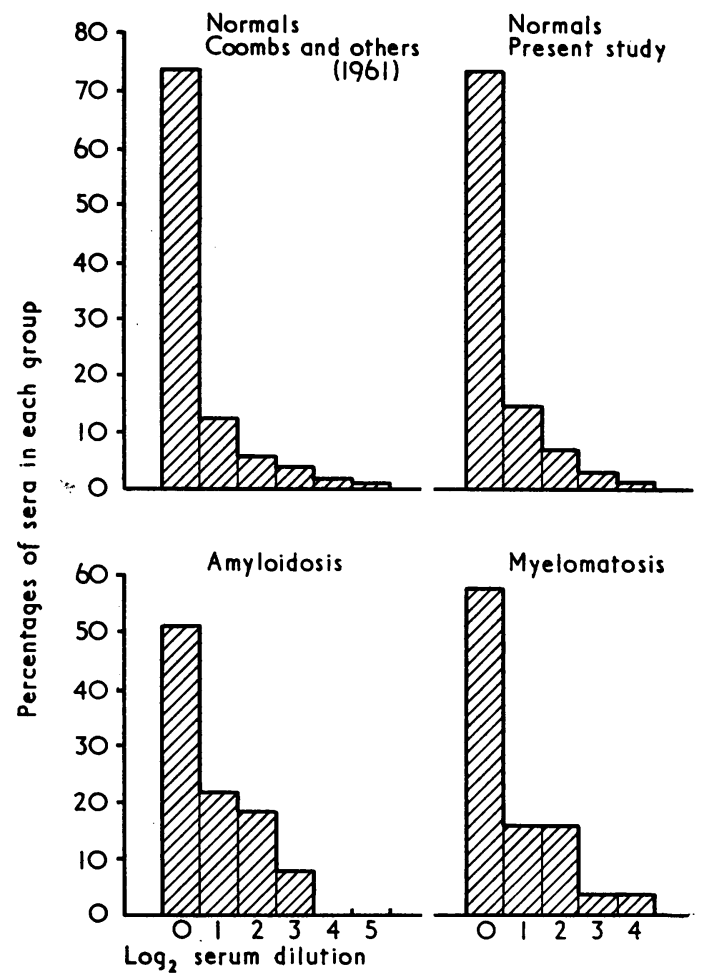

Fig.-Immunoconglutinin titres expressed as percentages of the populations of sera tested. Ordinates=percentages of sera groups; Abscissae $=\log _{2}$ serum dilution.

(Coombs and others, 1961; Caspary and Ball, 1962; Percy, 1966), would actually have been expected to show very much higher levels.

Experimental amyloidosis may be associated with immunological incapacity (Muckle, 1968) and it seems possible that these patients with chronic inflammation and amyloidosis had in some measure lost the ability to mount a specific immune response to in-vivo bound $\mathrm{C}^{\prime} 3$ complement. So far as the activity and severity of amyloidosis could be assessed during the patients' lives, there was an impression of some association between unexpectedly low or negative immunoconglutinin levels and progressive or advanced amyloid disease.

Thus, the sera of two patients contained no activity although both had had extensive active chronic suppuration present for some time. Case 2 had grossly purulent massive bronchiectasis with advanced amyloidosis. Case 6 (Jan. 1965) with presumably early but actively progressive amyloid disease since proteinuria $(11 \mathrm{~g}$./day) had appeared for the first time 3 weeks before and rectal biopsy showed only moderate deposits of amyloid, had numerous profusely suppurating perineal sinuses.
It is interesting to note that this latter subject, cured of his gross perineal sepsis by surgery a month later and taking $1 \mathrm{~g}$. ascorbic acid daily, has over the subsequent 18 months twice produced immunoconglutinin titres of $1: 4$. His proteinuria has diminished to just over $1 \mathrm{~g}$./day, and a recent, second, rectal biopsy has shown very much less amyloid deposition than the first. These observations suggest that cure of his predisposing disease and, possibly, regression of his amyloidosis have been accompanied by return of capacity to react immunologically to bound $\mathrm{C}^{\prime} 3$ complement.

Furthermore, four other patients with active sepsis (Case 1, 3, 4, and 5) and three patients with active rheumatoid arthritis (Cases 15, 16, and 18), all with advanced and presumably progressive amyloidosis, showed no or only slightly raised immunoconglutinin levels in their sera. That these patients did not exhibit very high immunoconglutinin titres accompanying such active inflammatory diseases is remarkable in view of the findings of Coombs and others (1961), Caspary and Ball (1962), and Percy (1966) in similar cases without amyloidosis.

Nevertheless, although very suggestive, these few examples can hardly be accepted as conclusive? Certainly, amyloidosis is not always accompanied by complete immunological incompetence towards bound $\mathrm{C}^{\prime} 3$ complement, since several patients did show some immunoconglutinin activity in their sera. The most that can be ventured is that low immunoconglutinin titres in patients with active rheumatoid arthritis or active chronic massive sepsis may indicate the presence of amyloidosis. The connecting links are immunological incompetence towards the agent or organism causing the inflammation, with consequently diminished humoral immune reaction and immunological $C^{\prime} 3$ complement binding which, in turn, affords only weak stimulation to an impaired ability for immunoconglutinin response. If real, this association could provide a useful diagnostic tool, but its evaluation will require study of a much larger series of patients.

In view of this consideration of immunological incompetence, it will be apparent that the absence of notable immunoconglutinin elevations in these patients with amyloidosis cannot be accepted as excluding the possibility that immunological activity is involved in the development of the disease or formation of amyloid substance. However, it may be deemed unlikely that immune reactions would make any important contribution in the presence of significant immunological incompetence. 
Serum $C^{\prime} 3$ complement levels were found to be normal in twenty cases of primary and secondary amyloidosis (Ellis and Walton, 1958; Williams and Law, 1960), and in ten cases of myelomatosis and lymphomata without amyloidosis (Williams and Law, 1960), so that it would perhaps have been surprising to find that immunoconglutinin levels were unusually raised in such cases. However, Williams and Law (1960) found low or nonexistent serum $\mathrm{C}^{\prime} 3$ complement levels in seven examples of myelomatosis complicated by amyloidosis, raising the possibility that increased consumption of complement might be involved in this particular form of amyloid disease. The authors considered that this was not likely to be immunological in nature since they found no anticomplementary activity in the sera, and the present finding of no high immunoconglutinin titres in the sera of three such subjects supports their conclusion.

The patients with myelomatosis also seemed to show an inverse relationship between the immunoconglutinin titres and the severity of their condition, and a degree of immunological inadequacy may accompany this disease. However, in view of the small number of patients studied, lack of specific tests of immunological competence, or accurate assessment of the severity of the myelomatosis by paraprotein quantitation, valid conclusions cannot be drawn on this point.

\section{Summary}

Immunoconglutinin levels were estimated in random samples of serum from patients with various forms of amyloidosis, with myelomatosis, and with both diseases, and from normal persons. Elevations of statistical significance but of minor degree were found, particularly in the group of amyloid patients. In a number of these the elevations were very much less than would have been expected from the nature of their predisposing conditions, which suggested some associated loss of immunological competence. The results do not support the concept of an immunological basis for the formation of amyloid deposits but, because of the latter indication, cannot be considered as exclusive of this possibility.

I am indebted to my many colleagues who provided clinical data and serum samples from their patients; to Prof. D. J. Newell of the University of Newcastle upon Tyne Department of Industrial Health for statistical advice; to Mrs. E. Beattie for technical assistance; and to the Arthritis and Rheumatism Council for Research in Great Britain for Grant No. 18228 which in part supported this work.

\section{REFERENCES}

Caspary, E. A., and Ball, E. J. (1962). Brit. med. J., 2, 1514 (Serum immuno-conglutinin in multiple sclerosis, Hashimoto's disease, and rheumatoid arthritis).

Coombs, R. R. A., Coombs, A. M., and Ingram, D. G. (1961). "The Serology of Conglutination and its Relation to Disease". Blackwell, Oxford.

Ellis, H. A., and Walton, K. W. (1958). Immunology, 1, 234 (Variations in serum complement in the nephrotic syndrome and other forms of renal disease).

Kochem, H. G. (1966). Frankfurt. Z. Path., 75, 399 (Immun-histologische Befunde bei drei Fällen sekundärer menschlicher Amyloidose).

Lachmann, P. J., and Coombs, R. R. A. (1965). "Complement, conglutinin and immuno-conglutinin", in "Ciba Foundation Symposium: Complement", ed. G. E. W. Wolstenholme and J. Knight, p. 251. Churchill, London.

—, Müller-Eberhard, H. J., Kunkel, H. G., and Paronetto, F. (1962). J. exp. Med., 115, 63 (The localization of in vivo bound complement in tissue sections).

Letterer, E., Caesar, R., and Vogt, A. (1960). Dtsch. med. Wschr., 85, 1909 (Studien zur elektronenoptischen und immunmorphologischen Struktur des Amyloids).

Loeschcke, H. (1927). Beitr. path. Anat., 77, 231 (Vorstellungen über das Wesen von Hyalin und Amyloid auf Grund von serologischen Versuchen).

Muckle, T. J. (1968). Israel J. med. Sci. (in press) (Impaired immunity in the etiology of amyloidosis).

Müller-Eberhard, H. J., and Dalmasso, A. P. (1965). "The possible role of complement in autoaggressive processes", in "Ciba Foundation Symposium: Complement", ed. G. E. W. Wolstenholme and J. Knight, p. 313 . Churchill, London.

Nowoslawski, A., and Brzosko, W. (1965). Pat. pol., 16, 205 (Analiza immunohistochemiczna amyloidu). 
Percy, J. S. (1966). Thesis, University of Newcastle upon Tyne (Immunoconglutinin in rheumatoid arthritis).

Strukov, A. I., Serov, V. V., and Pavlikhina, L. V. (1963). Virchows Arch. path. Anat., 336, 550 (On the pathogenesis of amyloidosis).

Vogt, A., and Kochem, H. G. (1960). Z Z Zellforsch., 52, 640 (Histo-serologische Untersuchungen mit fluoresceinmarkiertem Antikomplement nachweis komplementbindender Substanzen im Amyloid).

Williams, R. C., Jr., and Law, D. H., IV (1960). J. Lab. clin. Med., 56, 629 (Serum complement in amyloidosis).

L'immunoconglutinine sérique dans l'amyloïdose et la myelomatose humaine

\section{RÉSUMÉ}

On détermina le taux de l'immunoconglutinine dans les prélèvements du sérum, pris au hasard, chez des malades atteints de différentes formes d'amyloïdose, de myélomatose et de deux maladies à la fois, ainsi que chez des personnes normales. Ces taux furent augmentés, mais cette augmentation, bien que statistiquement significative, fut peu importante, particulièrement dans le groupe des patients amyloïdes. Chez plusieurs d'entre eux l'élevation était étonnamment faible si l'on prend en considération la nature de leurs conditions prédisposantes, indiquant une perte de la compétence immunitaire. Ces résultats ne viennent pas à l'appui du concept d'une base immunitaire pour la formation des dépôts amyloïdes mais ils n'excluent pas sa possibilité.
La inmunoconglutinina sérica en la amiloidosis y la mielomatosis humana

\section{SUMARIO}

Se determinaron las cifras de inmunoconglutinina en sueros, recogidos al azar, de enfermos con diferentes formas de amiloidosis, de mielomatosis y de ambas enfermedades, así como de personas normales. Se encontró una aumentación de estas cifras estadísticamente significativa pero poco importante, particularmente en el grupo de los enfermos amiloides. En un cierto número de ellos el aumento fué inesperadamente débil cuando se considera la naturaleza de las condiciones predisponentes, indicando una pérdida asociada de la competencia inmunitaria. Estos resultados no ofrecen apoyo a la hipótesis de una base inmunitaria para la formación de depósitos amiloides pero tampoco excluyen su posibilidad. 